\title{
Taxonomic notes on two sibling species of Metellina from Asia (Araneae, Tetragnathidae)
}

\author{
Recep Sulhi Özkütük', Yuri M. Marusik²,3, Kadir Boğaç Kunt', Mert Elvericii,5
}

I Department of Biology, Faculty of Science, Anadolu University, TR-26470, Eskişehir, Turkey 2 Institute for Biological Problems of the North, Portovaya Street 18, Magadan 685000, Russia 3 Department of Zoology \& Entomology, University of the Free State, Bloemfontein 9300, South Africa 4 Department of Biological Sciences, Faculty of Arts and Sciences, Middle East Technical University, TR-06800 Ankara, Turkey 5 Department of Biology, Faculty of Science and Arts, University of Erzincan, TR-24100, Erzincan, Turkey

Corresponding author: Recep Sulhi Özkütük (sozkutuk@anadolu.edu.tr)

Academic editor: S. Li | Received 10 May 2017 | Accepted 17 August 2017 | Published 4 September 2017

http://zoobank.org/32D8CCBF-6914-4E07-947F-6C5E349597BC

Citation: Özkütük RS, Marusik YM, Kunt KB, Elverici M (2017) Taxonomic notes on two sibling species of Metellina from Asia (Araneae, Tetragnathidae). ZooKeys 695: 75-88. https://doi.org/10.3897/zookeys.695.13611

\begin{abstract}
Two sibling species, Metellina orientalis (Spassky, 1932) and M. kirgisica (Bakhvalov, 1974), occurring in the Middle East and Central Asia are redescribed and their distributions mapped. The previously unknown male of $M$. kirgisica is described for the first time. Stridulatory files on male chelicera of Metellina are also documented for the first time. The occurrence of M. kirgisica in Azerbaijan and Tajikistan and the presence of $M$. orientalis in Turkey are confirmed.
\end{abstract}

\section{Keywords}

Anatolia, Aranei, Metainae, Caucasus, Central Asia, Iran, new record, description

\section{Introduction}

Metellina Chamberlin \& Ivie, 1941 is a small genus of Metainae spiders with seven named species occurring in the Holarctic (World Spider Catalog 2017). Two species, M. curtisi (McCook, 1894) and M. mimetoides Chamberlin \& Ivie, 1941, are restricted to the Nearctic and all other species are known from West Palaearctic (from the Iberian Peninsula to Xinjiang). Three species occurring in Europe and both species known from the Nearctic are well studied due to several publications (Levi 1980; Roberts 1995, etc.). 
Two easternmost Palaearctic species, M. kirgisica (Bakhvalov, 1974) and M. orientalis (Spassky, 1932), are the least known species of the genus. The former is known by females only and sketchy drawings; although $M$. orientalis is relatively well known, some essential characters of this species are not documented, such as the cymbial spines or stridulatory files on male chelicera, as well as the stiff setae present on legs I and II. Distributions of the two species are not properly known due to past misidentifications. Difficulties were faced in discriminating between these two species during studies of Turkish, Caucasian, and Central Asian spiders; therefore, a comparative study of $M$. kirgisica and $M$. orientalis is provided.

\section{Materials and methods}

Specimens were photographed with a Canon EOS 7D camera attached to an Olympus SZX16 stereomicroscope and Leica DFC295 camera connected to a stereo microscope Leica S8AP0. SEM figures were made with a SEM JEOL JSM-5200 scanning microscope at the Zoological Museum, University of Turku, Finland and with a Zeiss Ultra Plus SEM device at the Anadolu University, Eskişehir. Digital images were montaged using CombineZP image stacking software. The epigyne was cleared in a $\mathrm{KOH} /$ water solution until soft tissues were dissolved. Photographs were taken in dishes with cotton or paraffin on the bottom to hold the specimens in position. All measurements are given in $\mathrm{mm}$. Materials studied here are deposited in the Zoological Museum of the Moscow State University (ZMMU), Zoological Institute of St-Petersburg (ZISP), Zoological Museum, University of Turku (ZMUT), and Anadolu University, Zoological Museum (AUZM).

\section{Taxonomy}

Metellina Chamberlin \& Ivie, 1941

Metellina Chamberlin \& Ivie, 1941: 14; Levi 1980: 32; Álvarez-Padilla and Hormiga 2011: 779 .

Type species. Pachygnatha curtisi McCook, 1894 from California.

Diagnosis. See Levi (1980) and Álvarez-Padilla and Hormiga (2011).

Metellina orientalis (Spassky, 1932)

Figs 1-6, 9-10, 17-19, 23-25, 29-36, 39, 47

Meta orientalis Spassky, 1932: 184, f. 5-8 (ð’ O).

Metellina orientalis: Marusik 1985: 139; Marusik 1986: 19, f. 1.1-3 (ぷ+o); Malek

Hosseini et al. 2015: 92, f. 3a-c (ठึ). 
Examined specimens. TURKEY: Konya Province: $1 \hat{\jmath}, 2 q$ (AUZM), Seydişehir District, Kuyucak Mountain, Kalafat Hill, Ferzene Cave (37²2'49.24"N 31 $50^{\circ}$ '2.10"E), 27.03.2011 (R.S. Özkütük); 59 (AUZM), Derebucak District, Çamlık Town, Körükini Cave $\left(37^{\circ} 20^{\prime} 53.94^{\prime N}\right.$ 313'38.53"E), 10.06.2011 (K.B. Kunt); $10^{\dagger}, 2$ q (AUZM), Derebucak District, Çamlık Town, Döllüönüini Cave (37²0'20.38"N 31³7'15.12"E), 10.07.2011 (R.S. Özkütük). Erzincan Province, 20, 4 오 (AUZM), Kemaliye District, Kozlupınar Village, Ala Cave (39¹3'5.63"N 38³4'20.71"E), 20.03.2015 (M. Elverici) Sivas Province, 30̄, 19 (AUZM), Şarkışla District, Alaman Village, Camılı Cave (39³5'8.91"N 36²15'12.13"E), 18.04.2016 (K.B. Kunt). ARMENIA: syntype 1ठ (ZISP), Goktscha Lake (=Sevan), Yelenovka, 13-16.08.1931 (M. Karpova). IRAN: Kohgiluyeh and Buyer-Ahmad Province, $1 \overbrace{}^{\Uparrow} 1 \uparrow$ (ZMUT), Nevel Cave, 28.08.2011 (M.J. Malek Hosseini).

Diagnosis. Males of $M$. orientalis can be easily distinguished from all congeners, except for M. kirgisica, by having strong cymbial spines (Figs 17-19, 23, 25) lacking in other species. The two sibling species can be distinguished by the shape of paracymbial $\operatorname{spur}(P s)$, which are rounded and claw-like in $M$. orientalis (Figs 19, 23) and spine-like in $M$. kirgisica (Figs 21-22). Females of $M$. orientalis are also very similar to those of $M$. kirgisica by having three pairs of abdominal humps (can be almost indistinct in some specimens) and a very similar epigyne. The epigyne in $M$. orientalis has a larger and wider median plate (cf. Fig 36, 39-40, 42) and a thinner "septum" (1/3 of median plate width vs. 1/2). Females can be easily distinguished by carapace pattern, poorly developed in $M$. orientalis (Fig. 4-5) and very complex in M. kirgisica (Figs 11-12).

Description. Measurements $(\hat{\partial} /+$ ) : total length 6.48/6.60; carapace 2.88/2.70 long, 2.24/2.04 wide; chelicerae 1.20/1.20 long; abdomen 3.60/3.90 long, 2.40/3.12 wide.

Female carapace with weak pattern (Fig. 5) or almost lacking any pattern (Fig. 4). Legs with numerous spines, stronger in males than in females. Legs light-coloured; femora, tibia and metatarsi of all legs with two dark rings (Figs 1, 4-6). Tibia-metatarsi of legs I and II with prolateral row of stiff, inflexible setae forming kind of catching basket. For leg measurements see Table 1.

Abdomen with three pairs of humps, almost indistinct in males. Anterior pair large and distinct in all females examined, two posterior pairs much smaller and can be indistinct. Pattern not distinct, in contrast to sibling species; venter with wide dark median band.

Male chelicera with five strong stridulating ridges and some smaller ones above and below. Male palp as in Figs 17-19, 23, 24, 30-33. Cymbium with more than a

Table I. Leg measurements of Metellina orientalis.

\begin{tabular}{|c|c|c|c|c|c|c|}
\hline 119 & $\mathrm{Fe}$ & $\mathbf{P a}$ & $\mathrm{Ti}$ & Mt & Ta & Total \\
\hline I & $3.50 / 3.60$ & $1.44 / 1.40$ & $4.00 / 3.60$ & $4.40 / 4.00$ & $1.60 / 1.50$ & $14.98 / 14.14$ \\
\hline II & $3.10 / 3.00$ & $1.20 / 1.14$ & $3.00 / 2.22$ & $3.40 / 3.06$ & $1.20 / 1.00$ & $11.90 / 10.42$ \\
\hline III & $2.00 / 2.10$ & $0.75 / 0.84$ & $1.50 / 2.04$ & $1.80 / 1.62$ & $0.65 / 0.78$ & $6.70 / 7.38$ \\
\hline IV & $2.88 / 2.94$ & $0.78 / 0.84$ & $2.10 / 2.28$ & $2.40 / 2.40$ & $0.90 / 0.90$ & $9.06 / 9.36$ \\
\hline
\end{tabular}




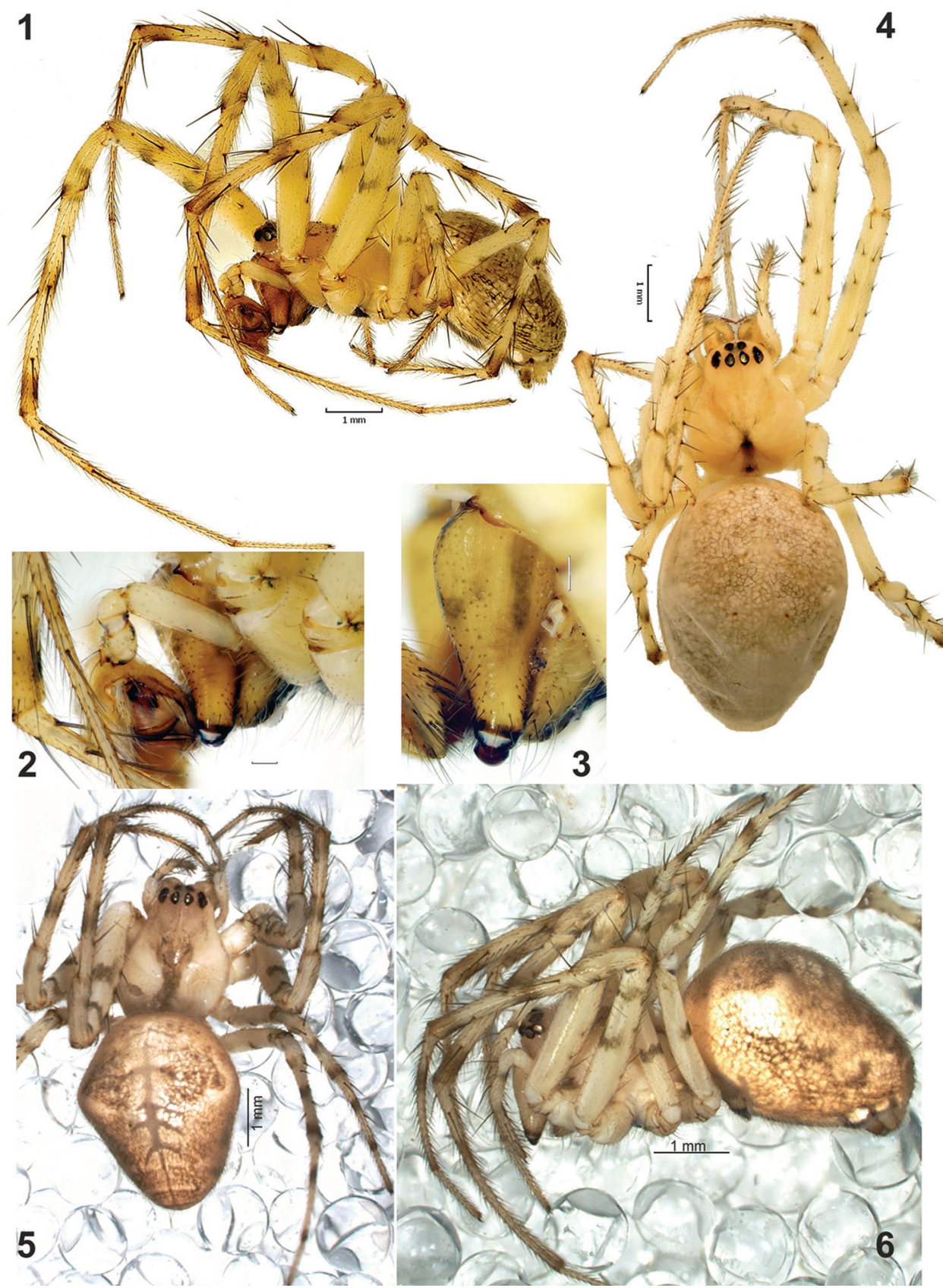

Figures I-6. Somatic characters of Metellina orientalis. I male habitus, lateral 2-3 anterior part of prosoma showing chelicera with stridulating ridges 4-5 female habitus, dorsal; $\mathbf{6}$ female habitus, lateral. Scale bars $1 \mathrm{~mm}(\mathbf{I}, \mathbf{4}, \mathbf{5}, \mathbf{6}) ; 0.2 \mathrm{~mm}(\mathbf{2})$. 
dozen strong macrosetae in distal half. Paracymbium with finger-like ventral arm $(P v)$ covered with setae and a large extending dorso-retrolateral arm $(P d)$. Dorso-retrolateral arm gradually widens, its width subequal to width of cymbium. Dorso-distal part of the arm with deep depression dorsally $(D d)$, spur like process $\left(P_{s}\right)$ and several rows of fine spines $\left(F_{s}\right)$ clearly visible with SEM, but indistinct with light microscopy. Tegulum thin, as wide as conductor, transverse. Conductor $(C o)$ long, with parallel margins, tip abrupt, with small membranous outgrowth $(M o)$, conductor entirely hides embolus in ventral view; embolus $(E m)$ with large base $(E b)$ formed by two lobes; embolus gradually tapering, with widened tip.

Epigyne as in Figs 34-36, 39; simple, heavily sclerotized plate more than twice as wide than long, without any outgrowths; median plate $(M p)$ with septum-like sclerotised outgrowth $(S e)$ three times thinner than width of median plate; median plate hexagonal, weakly sclerotized, wider than long. Anterior from epigynal plate with pair of transversal sclerotized plates (Sp, Fig. 34).

Distribution and notes. World Spider Catalog (2017) indicates distribution of the species as "Central Asia, Iran" although it was described from Armenia, located in the Caucasus and neighbouring with Turkey, which belong to the Middle East. Mikhailov's catalogue (Mikhailov 2013) indicates the distribution of M. orientalis in the former USSR as Armenia, Kazakhstan, and Turkmenistan: Metellina orientalis was reported from Kazakhstan (Almaty) and Turkmenistan (Akhal-Teke) by Spassky (1952) but the two records of the species from Central Asia undoubtedly refer to the sibling species $M$. kirgisica, previously reported from Kyrgyzstan, Uzbekistan, Turkmenistan (Mikhailov 2013), and northwestern China, Xinjiang (Marusik et al. 2007).

This species was reported from Turkey for the first time by Karol (1967). She referred to Spassky (1932) and Charitonov (1936), although none of these publications deal with spiders of Turkey. Spassky (1932) described it from Armenia, and Charitonov (1936) just listed the species in his catalogue. Several surveys and checklists of Turkish spiders listed this species as occurring in Turkey with reference to Karol's (1967) publications (Bayram 2002; Topçu et al. 2005; Bayram et al. 2017). Now we are able to confirm the presence of $M$. orientalis in Turkey.

\section{Metellina kirgisica (Bakhvalov, 1974)}

Figs 7-8, 11-15, 20-22, 26-28, 37-47

Meta orientalis: Spassky, 1952: 1977-198 (misidentification).

Meta kirgisicus Bakhvalov, 1974: 101, f. 6-7 (P).

Meta kirgisica Bakhvalov, 1982: 136, f. 1 (ㅇ); Bakhvalov 1983: 86, f. 1 (ㅇ).

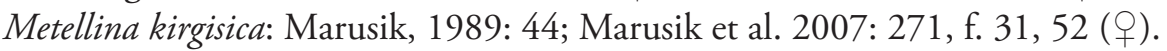

Material examined. AZERBAIJAN: Lenkoran Dist.: 1 ㅇ (ZMMU), env. of Auro-

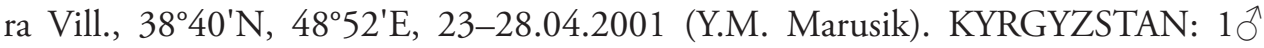
(lost), Kirgizian Mt. Range, Ala-Archa River, ca. $42.645^{\circ} \mathrm{N} 74.480^{\circ} \mathrm{E}, 8.05 .1983$ (S.V. 


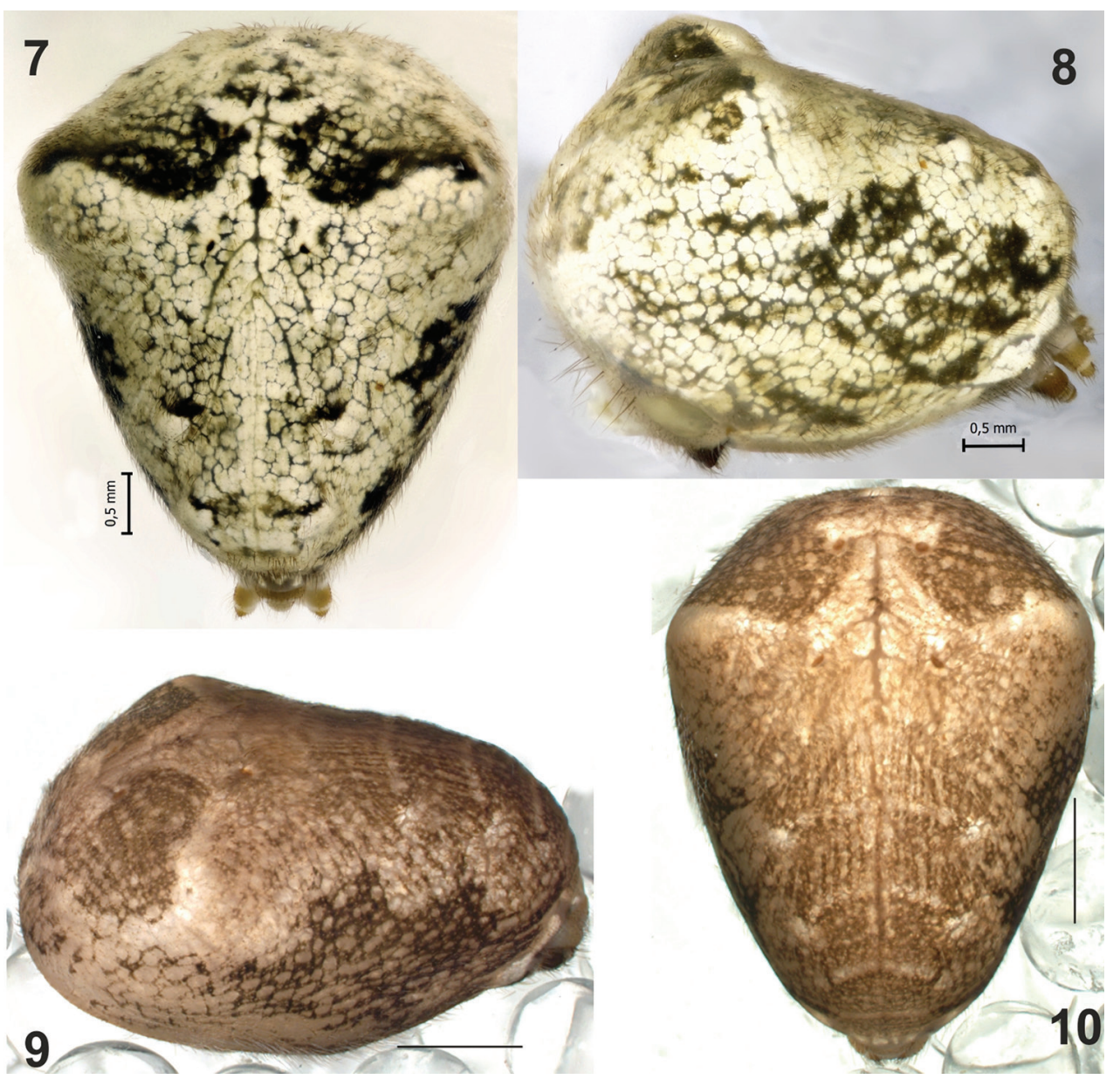

Figures 7-10. Abdomen of Metellina kirgisica (7-8) from Azerbaijan and M. orientalis (9-10) from Erzincan Province of Turkey. 7, 10 dorsal 8-9 lateral. Scalebars $0.5 \mathrm{~mm}(\mathbf{7}, \mathbf{8}) ; 1 \mathrm{~mm}(\mathbf{9}, \mathbf{1 0})$.

Ovtchinnikov); 19 (lost), Chatkal Mt. Range, Sary-Chelek Reserve, Karangitun Gorge, ca. $41^{\circ} 40^{\prime} \mathrm{N}, 71^{\circ} 56^{\prime} \mathrm{E}, 3.05 .1983$ (S.L. Zonstein). TAJIKISTAN: Khatlon Area: 49 (ZMMU), Vose Distr., Khodzha-Mumin Mt., 37²45.941'N, 69³8.665'E, 474 m, 25.04.2015 (Y.M. Marusik); 1 ( (ZMMU), Khovaling Distr., Darai-Mukhtor, env. of "Vose Museum", 38²3.572'N, 6957.910'E, 1579 m, 28.04.2015 (Y.M. Marusik); 2 우 (ZMMU) Hissar Mt. Range, Ramit Reserve, 3844.605'N, 69¹8.486'E, 1324 m, 1.05.2015 (Y.M. Marusik); 1 (ZMMU), environs of Dushanbe, Hissar Mt. Ridge, $38^{\text {th }} \mathrm{km}$ of Varzob Hwy, Takob Gorge, env. of Dehmalik Vill, $38^{\circ} 50.829^{\prime} \mathrm{N}$, 68 54.637'E, 805 m, 8.05.2015 ( Y.M. Marusik \& M. Saidov). CHINA, Xinjiang Province 1 ( $\left(\right.$ ZMUT), $70 \mathrm{~km}$ southwest of Urumqi, Nantaizi, $43.399^{\circ} \mathrm{N}$ to $43.438^{\circ} \mathrm{N}$, $87.214^{\circ} \mathrm{E}$ to $87.262^{\circ} \mathrm{E}, 1800-2100 \mathrm{~m}, 3.05 .-28.06 .2004$ (N.R. Fritzén). 


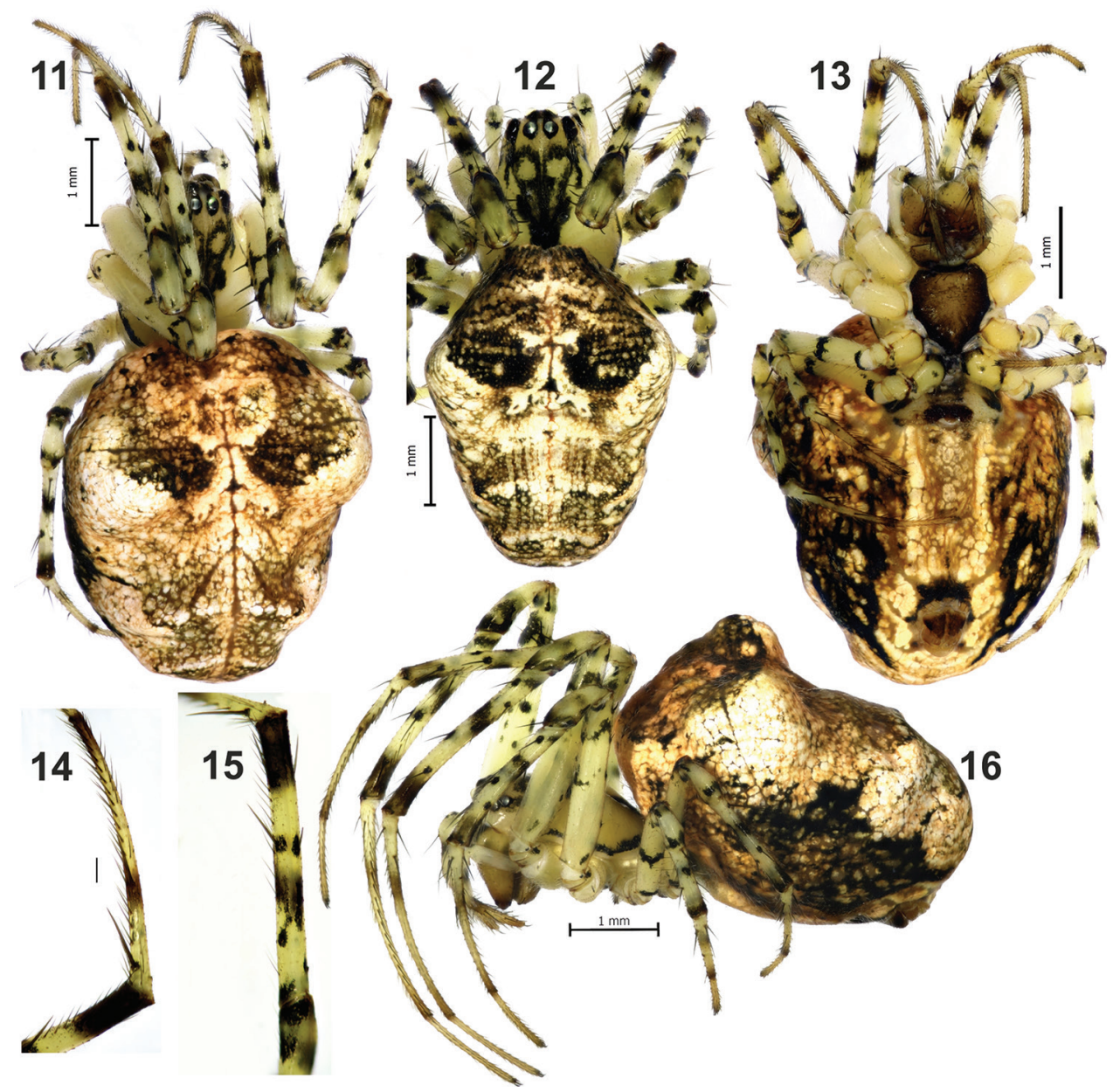

Figures I I-I6. Somatic characters of Metellina kirgisica female from Tajikistan. I I-I $\mathbf{2}$ habitus, dorsal, showing differences in size and colour pattern 13, 16 habitus, ventral and lateral 14 metatarsus I prolateral, showing row of stiff setae $\mathbf{I} \mathbf{5}$ tibia I, prolateral. Scale bars $1 \mathrm{~mm}(\mathbf{I} \mathbf{I}, \mathbf{I} \mathbf{2}, \mathbf{I} \mathbf{3}, \mathbf{I 6}) ; 0.2 \mathrm{~mm}(\mathbf{I} \mathbf{4})$.

Note. Bakhvalov (1974) described Meta kirgisicus only in a key to the orb-weaving spiders of Kyrgyzstan. The type material was not mentioned. In the subsequent paper Bakhvalov (1982) described the same species as Meta kirgisica on the basis of the holotype female and several paratypes. This description was supplemented with new figures. A year later this species was described again based on the same material and figures (Bakhvalov, 1983). Bakhvalov $(1982,1983)$ indicated that types will be deposited in the Laboratory of Entomology of the Institute of Biology of Kirgizian Academy of Sciences. According to Sergei L. Zonstein (pers. comm.), who was working in that laboratory, Bakhvalov never deposited type specimens in the Laboratory of Entomology. After the death of Bakhvalov his private collection was taken by son, and its fate is unknown. 


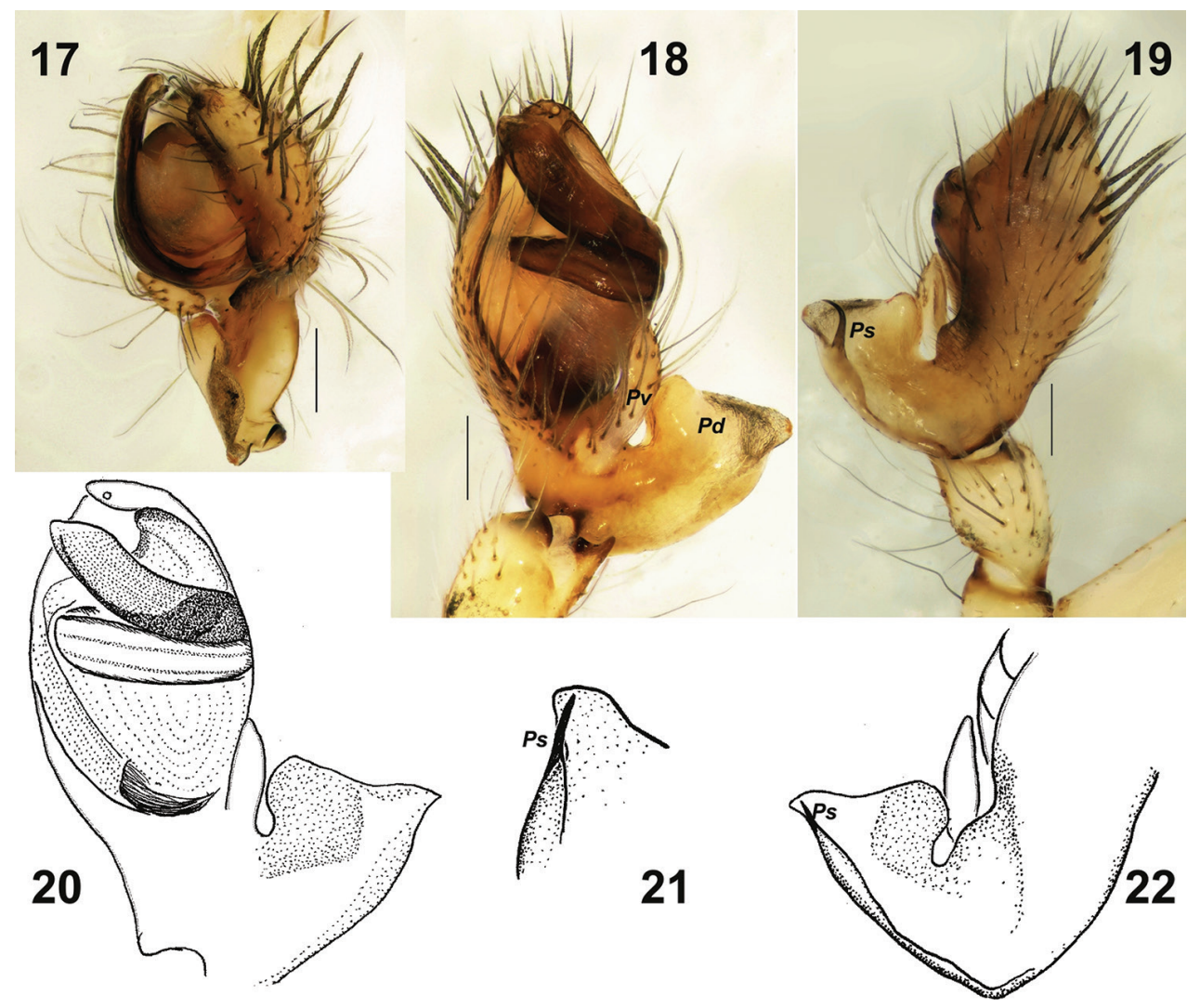

Figures 17-22. Male palp of Metellina orientalis (17-19) from Azerbaijan and M. kirgisica (20-22). $\mathbf{I}$ from above $\mathbf{1 8 , 2 0}$ ventral $\mathbf{1 9 ,} \mathbf{2 2}$ dorsal $\mathbf{2 1}$ tip of paracymbium with spur. $\boldsymbol{P} \boldsymbol{d}$ dorso-retrolateral arm $\boldsymbol{P}$ s spur like process $\boldsymbol{P} \boldsymbol{v}$ finger-like ventral arm. Scale bars $0.2 \mathrm{~mm}(\mathbf{I 7}, \mathbf{1 8}, \mathbf{1 9})$.

Diagnosis. Females of $M$. kirgisica can be distinguished from sibling $M$. orientalis by smaller size (carapace 2.0-2.1 long vs. 2.7), more developed pattern of carapace (cf. Figs 4-6 and11-12, 16), and proportions of the median plate of epigyne (as long as wide $v s$. wider than long). Males of the two species can be distinguished by the shape of paracymbial spur $\left(P_{s}\right)$, straight and spine-like in M. kirgisica and bent claw-like in M. orientalis (cf. Figs 19 and 21-22).

Description. Male. Measurements (male unavailable, specimen lost, palp was illustrated in 80 th by YM). Female: total length 4.5-5.5; carapace 2.0-2.1 long, 1.5-1.7 wide. Carapace yellow with complex dark pattern and distinct marginal dark stripe (Figs 11-12, 16). Legs yellowish with dark annulation and dark spots around base of each spine; femora, tibia and metatarsus of legs with two dark rings, rings of femora thick and thin on tibia and metatarsi; coxae IV with blackish dot (Fig. 13); distal half of tibia and metatarsi I and II with row of stiff setae forming a kind of catching basket (Figs 14-15). For leg measurements see Table 2. 


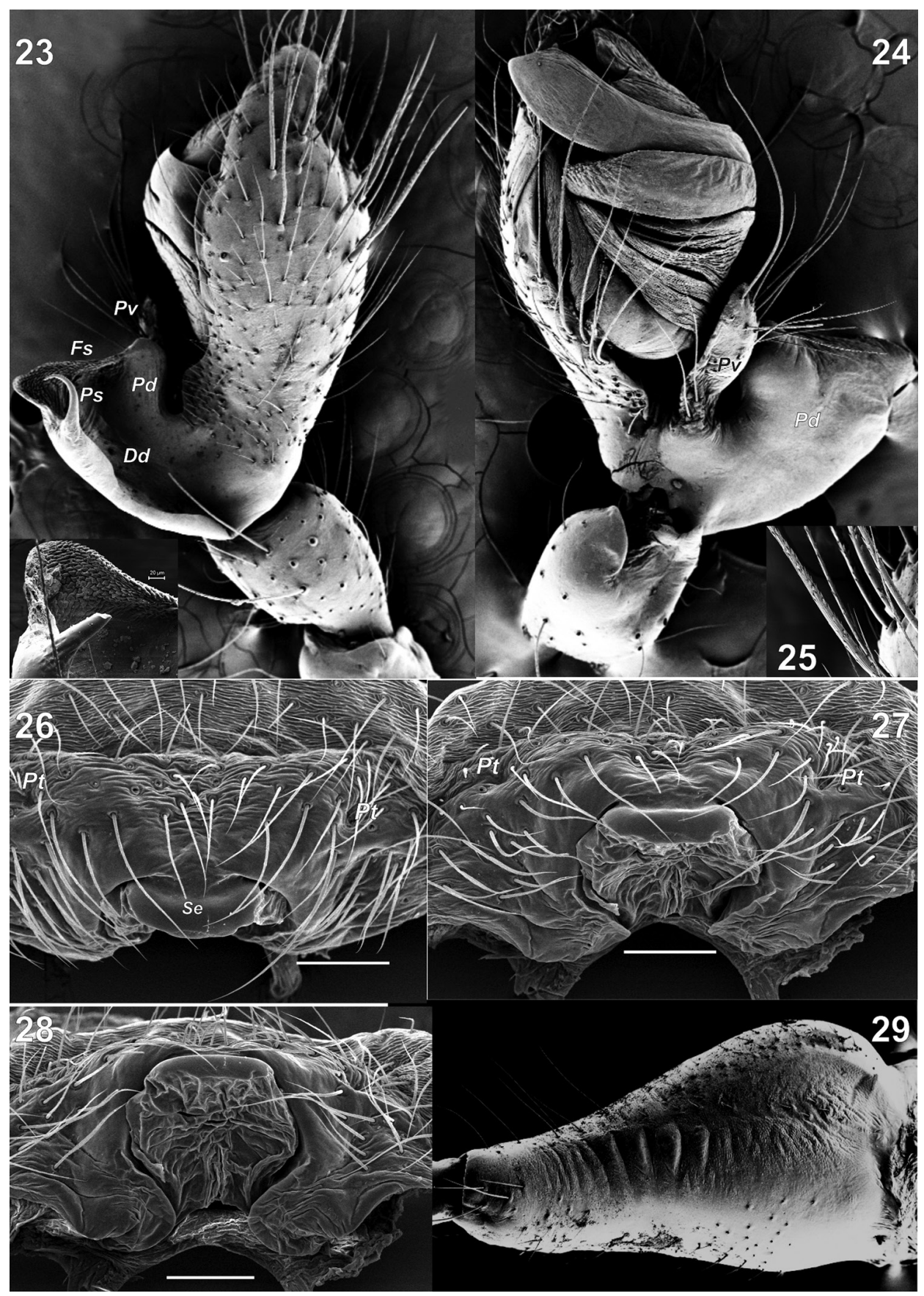

Figures 23-29. Copulatory organs and chelicera of Metellina orientalis $(\mathbf{2 3 - 2 5}, \mathbf{2 9})$ from Konya Province of Turkey and M. kirgisica (26-28). 23-24 male palp, dorsal and ventral 25 cymbial setae 26-28 epigyne, ventral, ventro-caudal and caudal 29 male chelicera, lateral. Abbreviations: $D d$ deep depression $F_{s}$ fine spines $P d$ dorso-retrolateral arm $P_{s}$ spur like process $P t$ lateral pits $P v$ finger-like ventral arm Se sclerotised outgrowth. Scale bars $0.2 \mathrm{~mm}(\mathbf{2 6}, \mathbf{2 7}, \mathbf{2 8})$. 

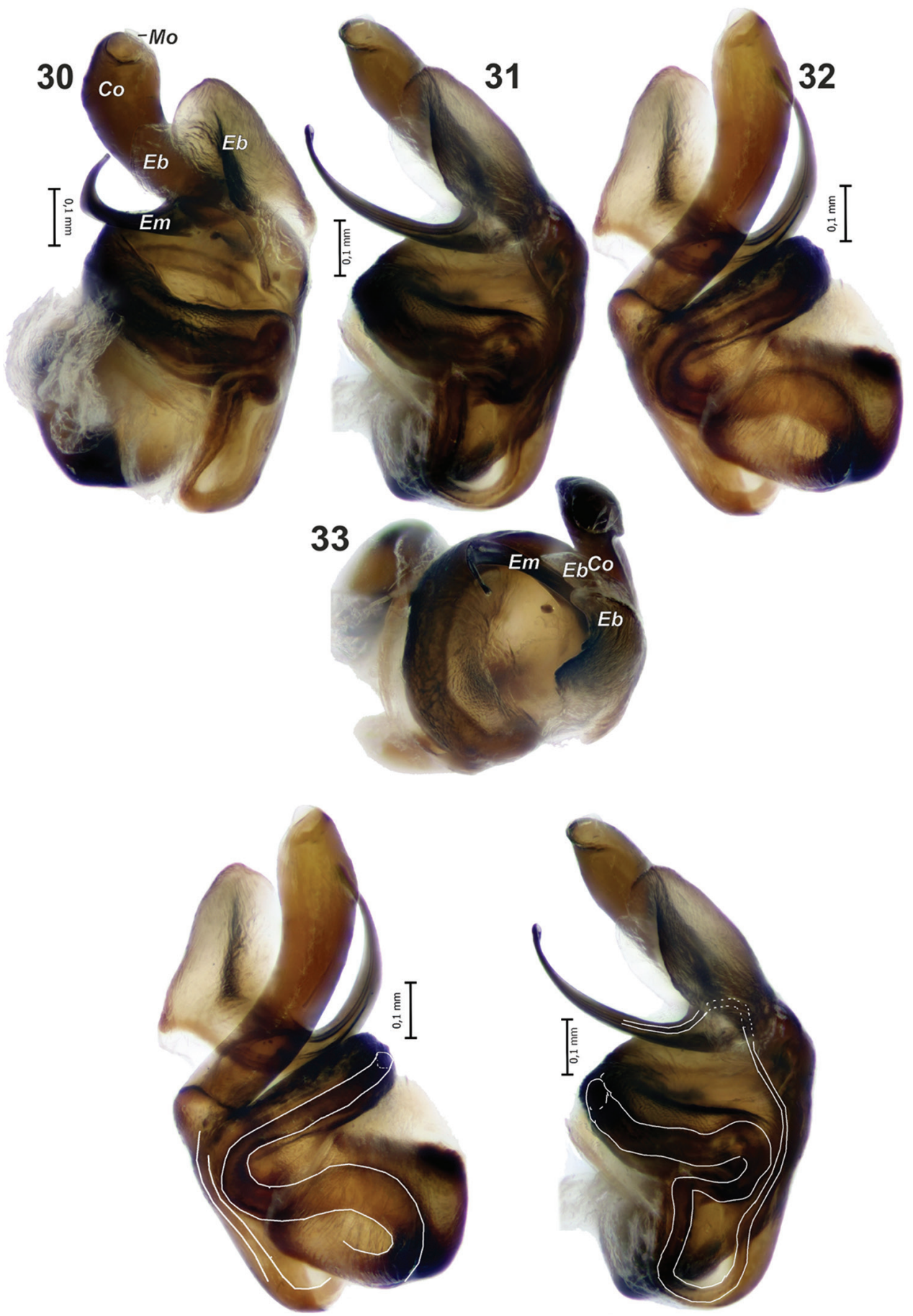

Figures 30-33. Bulb of Metellina orientalis. 33 from above. Abbreviations: Co conductor Eb embolar base Em embolus Mo membranous outgrowth. Scale bars $0.1 \mathrm{~mm}$. 

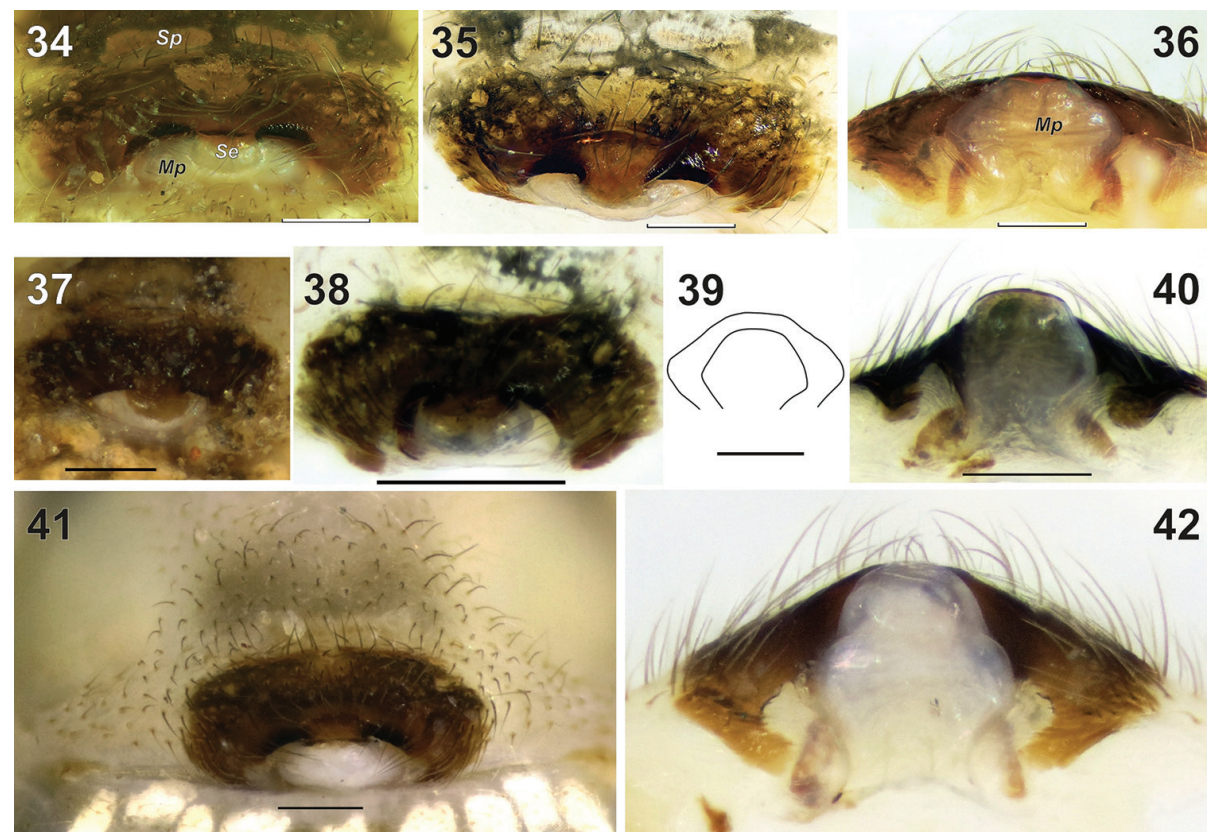

Figures 34-42. Epigynes of Metellina orientalis (34-36, 39) and M. kirgisica (37-42). 34-35, 37$\mathbf{3 8 , 4 I}$ ventral 36, 40, 42 caudal 39 outline of median plate of two species, showing differences in size and proportions 34-36 from Konya Province of Turkey 37-40 from Tajikistan 4I-42 from Azerbaijan. Abbreviations: $S p$ sclerotized plate $S e$ sclerotised outgrowth $M p$ median plate. Scale bars $0.2 \mathrm{~mm}$

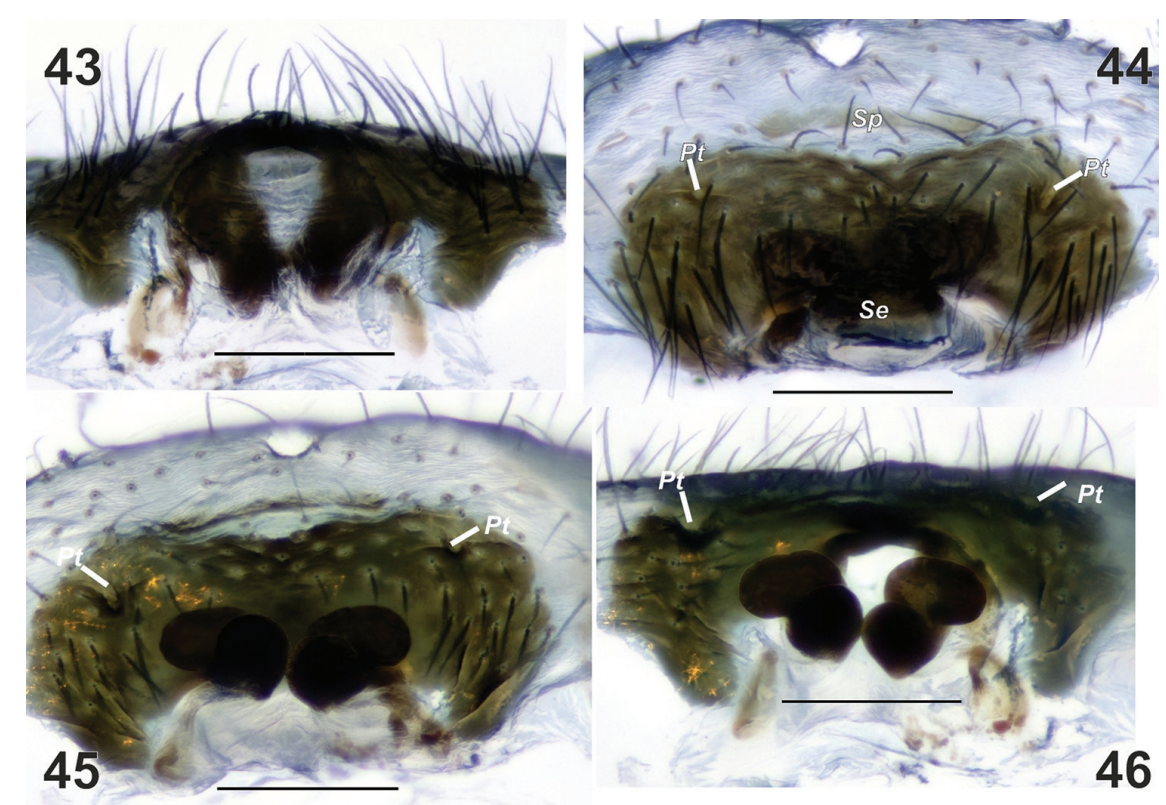

Figures 43-46. Macerated epigyne of Metellina kirgisica. 43 caudal 44 ventral 45 anterior $\mathbf{4 6}$ dorsal. $\boldsymbol{P t}$ lateral pits $\boldsymbol{S e}$ sclerotised outgrowth $\boldsymbol{S} \boldsymbol{p}$ sclerotized plate. Scale bars $0.2 \mathrm{~mm}$ 
Table 2. Leg measurements of Metellina kirgisica.

\begin{tabular}{c|c|c|c|c|c|c}
\hline P & Fe & Pt & Ti & Mt & Ta & Total \\
\hline I & 2.70 & 1.10 & 2.85 & 2.60 & 1.25 & 10.50 \\
\hline II & 2.20 & 0.90 & 1.80 & 2.10 & 0.95 & 7.95 \\
\hline III & 1.50 & 0.65 & 0.90 & 1.10 & 0.65 & 3.80 \\
\hline IV & 2.15 & 0.70 & 1.40 & 1.55 & 0.75 & 6.50 \\
\hline
\end{tabular}

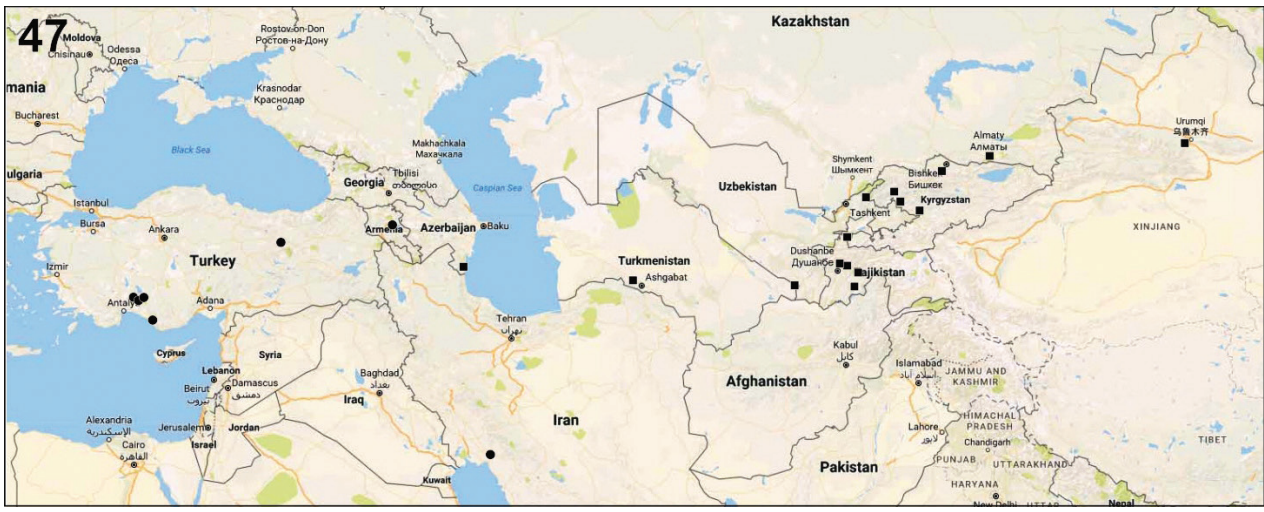

Figure 47. Distribution records of Metellina orientalis (circle) and M. kirgisica (square).

Abdomen with three pairs of humps, anterior the largest, two posterior humps less distinct. Abdomen with distinct pattern as shown on Figs 11-13, 16; venter with wide light band.

Palp as in Figs 20-22; spination of cymbium not documented; paracymbium with weakly sclerotised ventral arm and large and broad dorsal arm; dorsal arm with spinelike $\operatorname{spur}\left(P_{s}\right)$.

Epigyne as in Figs 26-28, 37-46; almost instinct transversal sclerotised plate ( $S p$, Fig. 44) in front of epigynal plate, epigynal plate twice as wide as long, heavily sclerotised with pair of small lateral pits $(P t)$; median plate $(M p)$ weakly sclerotised except kind of septum $(S e)$, septum twice as thin as median plate; median plate longer than wide; receptacles touching each other consisting of two lobes (Fig. 46).

Distribution. The species was previously known from Kyrgyzstan, Uzbekistan, Turkmenistan (Marusik 1989; Mikhailov 2013), and Xinjiang, China (Marusik et al. 2007). A search for literature records reveals that it was reported also from southeastern Kazakhstan (sub. M. orientalis: Spassky 1952). New material studied in this work reveals its occurrence in Tajikistan and eastern Azerbaijan (Fig. 47).

\section{Acknowledgements}

We thank Müjdat Çağlar (Eskişehir, Turkey) for provided assistance with SEM photography, Seppo Koponen (Turku, Finland) for arranging YM's stay in Turku and 
work in the Zoological Museum, Alireza Zamani (Tehran, Iran) for providing comparative specimens from Iran, and Kirill Mikhailov (Moscow, Russia) for consultations on the distributions of M. kirgisica and M. orientalis in Central Asia. This study was supported by Anadolu University Scientific Research Projects Commission under the grant no: 1503F093.

\section{References}

Álvarez-Padilla F, Hormiga G (2011) Morphological and phylogenetic atlas of the orb-weaving spider family Tetragnathidae (Araneae: Araneoidea). Zoological Journal of the Linnean Society 162: 713-879.

Bakhvalov VF (1974) Identification key of the spider family Araneidae from Kirgizia. Entomologiceskie issledovanija v Kirgizii 9: 101-112. [In Russian]

Bakhvalov VF (1982) New species of spiders (Aranei, Araneidae) from Tyan-Shan. Entomologicheskie issledovaniya v Kirgizii 15: 136-140. [In Russian]

Bakhvalov VF (1983) New species of spiders (Aranei, Araneidae) of USSR fauna. Entomologiceskie issledovaniya v Kirgizii 16: 86-94. [In Russian]

Bayram A (2002) Distributions of Turkish Spiders. In: Demirsoy A (Ed.) Zoogeography of Turkey. Meteksan Publications, Ankara, Turkey, 638-657. [In Turkish]

Bayram A, Kunt KB, Danışman T (2017) The Checklist of the Spiders of Turkey. Version 2017. http://www.spidersofturkey.info [accessed on 09 May 2017]

Charitonov DE (1936) Dopolneniye k katalogu russkich paukov Uchenye Zapiski Persmkogo Universiteta 2(1): 167-223. [In Russian]

Karol S (1967) Turkish spiders. I. Preliminary list. Printing office of Ankara University, Ankara, $34 \mathrm{pp}$.

Levi HW (1980) The orb-weaver genus Mecynogea, the subfamily Metinae and the genera Pachygnatha, Glenognatha and Azilia of the subfamily Tetragnathinae north of Mexico (Araneae: Araneidae). Bulletin of the Museum of Comparative Zoology at Harvard College 149: 1-74.

Malek Hosseini MJ, Zamani A, Sadeghi S (2015) A survey of cave-dwelling spider fauna of Kohgiluyeh \& Boyer-Ahmad and Fars Provinces, Iran (Arachnida: Araneae). Revista Ibérica de Aracnología 27: 90-94.

Marusik YM (1985) A systematic list of the orb-weaving spiders (Aranei: Araneidae, Tetragnathidae, Theridiosomatidae, Uloboridae) of the European part of the USSR and the Caucasus. Trudy Zoologicheskogo Instituta Akademii Nauk SSSR 139: 135-140. [In Russian]

Marusik YM (1986) A redescription of types of certain orb-weaving spiders (Araneidae, Tetragnathidae) from S. A. Spassky collection. Vestnik Zoologii 6: 19-22. [In Russian]

Marusik YM (1989) New data on the fauna and synonymy of the USSR spiders (Arachnida, Aranei). In: Lange AB (Ed.) Fauna i ekologiya paukov i skorpionov: Arakhnologicheskiy Sbornik. Akademia Nauk SSSR, Moscow, 39-52. [In Russian]

Marusik YM, Fritzén NR, Song DX (2007) On spiders (Aranei) collected in central Xinjiang, China. Arthropoda Selecta 15: 259-276. 
Marusik YM, Larsen N (in press) A synopsis of African Metellina (Araneae, Tetragnathidae, Metinae) with a description of new species from South Africa. Vestnik Zoologii.

Marusik YM, Özkütük RS, Kunt KB (2012) Spiders (Araneae) new to the fauna of Turkey. 10. Two new species records of Tetragnathidae. Anadolu University Journal of Science and Technology C2(2): 69-73.

Mikhailov KG (2013) The spiders (Arachnida: Aranei) of Russia and adjacent countries: a nonannotated checklist. Arthropoda Selecta Supplement 3: 1-262.

Roberts MJ (1995) Collins Field Guide: Spiders of Britain \& Northern Europe. HarperCollins, London, $383 \mathrm{pp}$.

Spassky SA (1932) Aranearum species novae. Bulletin du Muséum National d'Histoire Naturelle de Paris (2)4: 182-189.

Spassky S (1952) Spiders of the Turanian zoogeographical province. Entomologicheskoe Obozrenie 32: 192-205. [In Russian]

Topçu A, Demir H, Seyyar O (2005) A Checklist of the spiders of Turkey. Serket 9(4): 109-140.

World Spider Catalog (2017) World Spider Catalog. Natural History Museum Bern. http:// wsc.nmbe.ch, version 18.0 [accessed on 27 April 2017] 